\title{
A Retrospective Look at the Effect of Auditor Specialization and Industry Concentration on the Cost of Audit Services
}

\author{
Jeffrey R. Casterella, ${ }^{1,2}$, Rosemond $\operatorname{Desir}^{1} \&$ Gretchen $\operatorname{Irwin}^{1}$ \\ ${ }^{1}$ Department of Accounting, Colorado State University, USA \\ ${ }^{2}$ University of Auckland, New Zealand \\ Correspondence: Jeffrey R. Casterella, E\&Y Faculty Fellow and Associate Professor, Department of Accounting, \\ Colorado State University, USA \& University of Auckland, New Zealand
}

Received: April 30, 2013

Accepted: May 16, 2013

Online Published: May 16, 2013

doi:10.5430/afr.v2n2p79

URL: http://dx.doi.org/10.5430/afr.v2n2p79

\begin{abstract}
The purpose of this paper is to perform a retrospective, pre-merger look at the effect of concentration and specialization on audit fees when there were 6 large accounting firms (i.e. the "Big 6"). The US General Accountability Office (GAO) reviewed the effects of auditor concentration on the market for audit services. The 2008 GAO report includes some discussion of the possibility that one or two of the largest sell off a substantial portion of their business which would revert the Big 4 back to the Big 5 or Big 6 . Because of the concern over concentration in the audit market and the future possibility of returning to a market that would consist of more than 4 large accounting firms, we conduct a retrospective look at pricing behavior in the audit market when it was less concentrated.Using a sample of 653 U.S. public companies audited by the Big 6, we find that specialists charged more for their services unless they are in competition with other specialists in concentrated industries.
\end{abstract}

Keywords: Auditor specialization, Concentration, Fees

\section{Introduction}

Recently, the US General Accountability Office (GAO) reviewed the effects of auditor concentration on the market for audit services. The GAO reports that as of 2006 approximately $98 \%$ of public companies are audited by the Big 4 . Over the past 30 years, the number of large accounting firms has decreased from what was known as the "Big 8" to the "Big 4". With the resulting increased concentration, the GAO and Congress are concerned that the competiveness of the remaining 4 firms might be reduced. Some have suggested that one or more of the Big 4 firms "spin off" some of their clients to increase the number of large public accounting firms (GAO 2008, 54). Furthermore, the GAO is concerned about further concentration if one of the largest firms ceases to exist as the result of litigation or regulatory action. To investigate the effects of concentration on the audit services market, the GAO study collected audit fee data for the period 2000 to 2006 and reported that increased concentration was not adversely affecting competition in the market for audit services. However, the GAO adds that the findings "should not necessarily be viewed as definitive or as proof that the market of audit services is competitive." In addition, the GAO notes that it is unable to investigate the relationship between concentration and audit fees in earlier periods because of a lack of publicly available data prior to the year 2000 (GAO 2008, 96).

The purpose of this paper is to perform a retrospective, pre-merger look at the effect of concentration and specializationon audit fees when there were 6large accounting firms (i.e. the "Big 6"). This "retrospective look" can offer some insight into the competitive environment that the Big 6 firms faced in the period prior to the year 2000 and its effect on audit fees.Such benchmarking data should be useful to regulators in their continued efforts to monitor the effects of concentration in the market for audit services.Our proprietary data set consists of 1993 audit fees for 653 publicly held companies, all of which were audited by the Big 6 .

We find evidence of a negative sign on the effect of specialization when there is concentration, indicating that specialists in a competitive environment charge less for audit services. This result is bolstered by our other results. For example, we also find that concentration does not affect fees when the auditor is not a specialist. We further find evidence of a positive effect for specialization, indicating that, other things being equal, specialists charge more for their audit services. Our results are consistent with the notion that auditors exploit the economic advantage of specialization unless competition from other specialists prevents them from doing so. In addition, our results suggest 
that since pricing is essentially a competition issue, we cannot fully understand its complexities unless we jointly look at competition and specialization.

The remainder of this paper is organized as follows. In the next section, we briefly review the prior literature relating to specialization and concentration and their effect on audit fees. This is followed by a discussion of the model and the corresponding variables we use to test the joint effects of specialization and competition. Sections four and five discuss our sample data and our results, respectively. The final section provides some conclusions and a discussion of our results.

\section{Background}

Auditor specialization refers to an audit firm's unique expertise in an industry. Prior research has shown that client firms pay a premium to auditors that are considered to be specialists in the clients' industry (Craswell et al., 1995; Defond et al., 2000; Casterella et al., 2004). (Note 1) Specialist auditors are seen to be providing a higher quality audit service to their clients(Simunic, 1980) and are, actually, sought out by audit committees that are both "active" and "independent" (Abbott and Parker, 2000). However, the link between auditor specialization and audit fees is "not clear-cut" (Hay et al., 2006). Hay et al. (2006) report that, out of nine studies that investigate a relationship between auditor specialization and audit fees, only three studies find a significant relation. For example, Palmrose (1986) investigated the relationship between audit firm size and audit fees. Her sample consisted of 361 U.S. public and non-public companies in 12 different industries. 1981 audit fee data was obtained by a questionnaire sent to auditees. Since total industry audit fees were not publicly available, industry market shares were calculated using publicly available clients' sales. The auditors with the three largest market shares of a given industry were coded as specialists in that industry. Using a model similar to that of Simunic (1980), she found no evidence that specialization affects fees. The overall model had an $\mathrm{R}^{2}$ of 89 percent. On the other hand, Casterella et al. (2004) used a sample of 651 client firms audited by the Big 6 auditors and found evidence that fees are higher for Big 6 industry specialists. However, their results only held for companies with total assets of less than \$123 million.

There is even less research on a link between audit fees and industry concentration. Industry concentration of audit firms pertains to the number of available audit firms and their respective shares of the audit market. Wolk et al. (2001) report that when the Big 8 became the Big 6 in 1989, regulators were concerned about the market for audit being in the hands of a few accounting firms. In 1998, Price Waterhouse merged with Coopers \& Lybrand to create PricewaterhouseCoopers raising even more concerns about market concentration. With the dissolution of Arthur Andersen following the 2001 Enron scandal, industry concentration becomes even a greater issue.

Bigus and Zimmermann (2008) studied the concentration of audit firms in the German market and find that the Big 4 accounting firms perform the audit in 66\% of the 175 cases they studied. In their 1994 study, Pearson and Trompeter investigated a potential relation between industry concentration and audit fees. They reported lower fees for audits performed in industries that are supplier concentrated. Their results were based on publicly available audit fee data between the years 1982 and 1986 for 241 U.S. insurance companies, all of which were audited by the Big 8. The model included variables to control for size, complexity and risk and two experimental variables: market leader and industry concentration. The market leader variable was coded one if a market leader audited the company, zero otherwise. The industry concentration variable was calculated using the share of industry market controlled by the top three auditors, based on total assets of the clients in the industry, relative to the industry market as a whole. They reported that fees are significantly and negatively related to concentration. The overall model had an $\mathrm{R}^{2}$ of 70 percent. However, the 2003 GAO Report (2003) which was mandated by the Sarbanes-Oxley Act of 2002 to study the implications of concentration on audit fees revealed "that increased concentration had reduced client choice, but did not seem to affect price competition in audit markets" (Kallapur et al., 2010, p. 1).

Given the sparse research and mixed results on a link between industry concentration and audit fees, as well as between auditor specialization and audit fees, the impact of the joint effect of these two factors on audit fees remains an empirical question. Moreover, the $2008 \mathrm{GAO}$ report includes some discussion of the possibility that one or two of the largest sell off a substantial portion of their business which would revert the Big 4 back to the Big 5 or Big 6 . The report suggests that such a move would "at least temporarily decrease concentration andmitigate the adverse effect of one of the firms exiting the market or failing" (GAO 2008, 54). Thisreport also points out that "other markets have been split up in the past" (GAO 2008, 54) (Note 2). Because of the concern over concentration in the audit market and the future possibility of returning to a market that would consist of more than 4 large accounting firms, we conduct a retrospective look at pricing behavior in the audit market when it was less concentrated. In the next section, we describe the model and provide definitions of independent variables. 


\section{The Model}

\subsection{Baseline Model Derived from Simunic (1980)}

Simunic (1980) posited three classes of variables expected to determine audit fees. The three classes are loss exposure, loss sharing ratio and learning by the auditor. Overall, his results indicate that audit fees are higher when the auditor faces larger and more complex clients (i.e., exposure to loss is higher) and when the client appears more risky (i.e., the auditor's loss sharing ratio is higher).

Simunic's model is as follows (Note 3):

$$
\begin{aligned}
\text { FEE } / \text { ASSETS }=\quad & a 0+\text { a1 SUBS.5 + a2 SEGMENTS }+ \text { a3 FOREIGN }+ \text { a4 REC }+ \text { a5INV }+ \\
& \text { a6UTILITY }+ \text { a7PROFIT }+ \text { a8LOSSES }+ \text { a9OPINION }+ \text { a1OLn TENURE }+ \\
& \text { a11PW }+ \text { error }
\end{aligned}
$$

Where:

\section{Dependent variable:}

FEE/ASSETS Amount of current year's external audit fee divided by total assets at year-end

\section{Control variables:}

$\begin{array}{ll}\begin{array}{l}\text { SUBS.5 } \\ \text { SEGMENTS }\end{array} & \begin{array}{l}\text { Square root of the number of subsidiaries } \\ \text { FOREIGN }\end{array} \\ \text { REC } & \begin{array}{l}\text { Percentage of assets that are foreign } \\ \text { Accounts, loans, and notes receivable divided by total assets } \\ \text { at year-end } \\ \text { Inventories divided by total assets at year-end }\end{array} \\ \text { INV } & \text { One if a public utility company (SIC code 49) } \\ \text { UTILITY } & \text { Net income divided by total assets } \\ \text { PROFIT } & \text { One if a loss in the past three years } \\ \text { LOSSES } & \text { One if audit opinion is modified for going concern } \\ \text { OPINION } & \text { Natural log of the number of years with the same auditor } \\ \text { Ln TENURE } & \text { One if Price Waterhouse \& Co. } \\ \text { PW } & \end{array}$

\subsection{Improved Model with the Inclusion of Auditor Specialization and Industry Concentration}

In this section, we describe the variable formulation used to test the relation between auditor specialization and audit fees. Based on prior research, it is clear that there are at least two issues that need to be considered when testing for a specialization effect. The first issue is whether a given auditor is a dominant auditor within an industry. Dominance is measured by market share and is a presumed indicator of specialization or expertise. The second issue is whether a given industry has dominant auditors, and if so, how many. This is an audit supplier concentration ratio and is an indicator of oligopolistic competition among specialists. Whereas Pearson and Trompeter (1994) test these components as separate linear variables, we argue that a more powerful test uses a different combination of the variables.

Since there are specialists in non-concentrated industries, we still include an independent variable for auditorspecialization (labeled SPEC). Specialization represents the auditor's specialization or expertise. On the other hand, by definition, there are no supplier concentrated industries without at least one (usually two or three) specialist. For this reason, we include a variable that indicates whether a specialist operates in a concentrated industry. Using contrast coding, we test whether industryconcentration affects the fees charged when the auditor is a specialist (labeled CONSPEC) and when the auditor is not a specialist (labeled CONNOSPEC), after controlling for the explanatory variables contained in the Simunic (1980) model. Based on the rationale that auditors will exploit a technical advantage unless competitive forces prevent it, we predict a positive coefficient for auditor specialization (SPEC) and a negative coefficient for auditor specialization in the presence of industry concentration (CONSPEC). We predict that concentration, in the absence of specialization (CONNOSPEC), will not lead to reduced fees. We define a specialist as an auditor who audits at least 20 percent of an industry. We measure concentration as any 
industry in which the top three auditors have at least a 75 percent market share. We later discuss the sensitivity of our results to these measures.

Using the measures discussed above, we create contrast-coded variables to test our hypotheses. Contrast codes are an alternative to dummy variables and are described as "simply one of the possible arbitrary coding schemes for numerically representing categorical predictors" (Judd and McClelland 1989, 283). With a priori thought as to the relationships among the variables, contrast codes allow testing more advanced research designs. As Buckless and Ravenscroft (1990) point out, they can also increase statistical power. Buckless and Ravenscroft explain how contrast codes could have been used in many prior research studies. The contrast coding of these variables is summarized in Table 1 (Note 4).

Table 1. Coding of Specialist and Concentration Variables

\begin{tabular}{lllll}
\hline & Specialist $=$ yes & Specialist $=$ no \\
\hline Test Variable: & $\begin{array}{l}\text { Concentration }= \\
\text { yes }\end{array}$ & $\begin{array}{l}\text { Concentration } \\
\text { no }\end{array}$ & $\begin{array}{l}\text { Concentration } \\
\text { yes }\end{array}$ & $\begin{array}{l}\text { Concentration }= \\
\text { no }\end{array}$ \\
\hline SPEC & +1 & +1 & -1 & -1 \\
CONSPEC & +1 & -1 & 0 & 0 \\
CONNOSPEC & 0 & 0 & +1 & -1 \\
\hline Specialist & $=$ Coded one if the audit firm has at least a 20 percent share of the industry \\
Concentration & $=$ Coded one if the top 3 auditors control at least 75 percent of the industry
\end{tabular}

In addition to these variables, the model includes one other piece of information gathered from our fee questionnaire (Note 5) that should be predictive of fees. The surveyed companies were asked to comment on any nonrecurring events and circumstances that they believed had an effect on their external audit fee. This variable (labeled COMMENT) was coded one for significant comments, zero for no comments or minor comments.

The model tested is:

$$
\begin{aligned}
\text { Ln FEE }= & b 0+b 1 \text { Ln SIZE }+ \text { b2 SUBS. } 5+\text { b3 SEGMENTS + b4 FOREIGN + } \\
& \text { b5 RECINV + b6 PROFIT + b7 LOSSES + b8 OPINION + b9 Ln TENURE + b10 } \\
& \text { SIC49 + b11 COMMENT + b12 SPEC + b13 CONSPEC + } \\
& \text { b14 CONNOSPEC + error }
\end{aligned}
$$

Where:

\section{Dependent variable:}

Ln FEE Natural log of audit fee in millions

Control variables:

Ln SIZE

SUBS.5

SEGMENTS

FOREIGN

RECINV

PROFIT

LOSSES

OPINION

Ln TENURE

SIC49
Natural log of total assets in millions

Square root of the number of subsidiaries

Number of business segments

Percentage of assets that are foreign

Accounts receivable plus inventory divided by assets

Net income divided by total assets

One if a loss in the past three years

One if audit opinion is modified for going concern

Natural $\log$ of the number of years with the same auditor

One if company is a utility company

\section{Experimental variables:}

COMMENT One if significant event affected audit fee

SPEC Specialist auditor, coded as described in Table 1




\section{CONSPEC Specialist in a concentrated industry, coded as described in Table 1 \\ CONNOSPEC Non-specialist in a concentrated industry, coded as described in Table 1}

Note that we have omitteda variable to control for audits performed by Price Waterhouse (PW) since the effect should be impounded in the experimental variables. For SEGMENTS we use the number of business segments from Compustat, whereas Simunic (1980) used the number of two-digit SIC industries. Finally, size is included as an independent variable rather than as a deflator of total fees. (Note 6)

\section{Sample Selection and Data Sources}

Survey questionnaires requesting 1993 audit fee data were sent to more than 3000 companies selected from the Compustat database. (Note 7) The selection criteria included Big 6 auditor, SIC code below 6000, and data availability on Compustat and Moody's. (Note 8) The questionnaires requested U.S. audit fees, non-U.S. audit fees, auditor tenure, the budget of their internal audit department, number of subsidiaries, and comments on any nonrecurring events and circumstances that affected the external audit fees. (Note 9) Of the companies surveyed, 774 responded, 653 of which have the necessary data available on Compustat. Market share information was collected from Compustat for 1994 and used to construct both a concentration level (for every 2 digit SIC code) and a specialist variable (for every auditor in an industry).

\section{Results}

Descriptive statistics for our sample of 653 companies are provided in Table 2, while Table 3 provides a correlation matrix. The average respondent had mean total assets of $\$ 1.8$ billion and an average audit fee of $\$ 512$ thousand. A review of the correlation matrix does not suggest any major correlation problems. (Note 10)

Table 2. 1993 descriptive statistics for 653 publicly listed U.S. companies

\begin{tabular}{lll}
\hline Variables & Mean & Standard deviation \\
\hline AUDIT FEE (Millions) & .51 & 1.37 \\
TOTAL ASSETS (Millions) & 1808.74 & 7325.51 \\
Ln SIZE & 5.14 & 2.08 \\
SUBS.5 & 2.70 & 3.16 \\
SEGMENTS & 1.63 & 1.11 \\
FOREIGN & 0.08 & 0.16 \\
RECINV & 0.32 & 0.22 \\
PROFIT & -0.01 & 0.21 \\
LOSSES & 0.46 & 0.50 \\
OPINION & 0.06 & 0.23 \\
Ln TENURE & 2.41 & 0.95 \\
SIC49 & 0.12 & 0.32 \\
COMMENT & 0.19 & 0.39 \\
SPEC & -0.31 & 0.95 \\
CONSPEC & 0.06 & 0.58 \\
CONNOSPEC & -0.00 & 0.81 \\
\hline
\end{tabular}

\begin{tabular}{ll}
\hline Ln SIZE & $=$ Natural log of total assets in millions \\
SUBS.5 & $=$ Square root of the number of subsidiaries \\
SEGMENTS & $=$ Number of business segments \\
FOREIGN & $=$ Percentage of assets that are foreign \\
RECINV & $=$ Accounts receivable plus inventory divided by assets \\
PROFIT & $=$ Net income divided by total assets \\
LOSSES & $=$ One if a loss in the past three years
\end{tabular}




$\begin{array}{ll}\text { OPINION } & =\text { One if audit opinion is modified for going concern } \\ \text { Ln TENURE } & =\text { Natural log of the number of years with the same auditor } \\ \text { SIC49 } & =\text { One if company is a utility company } \\ \text { COMMENT } & =\text { One if significant event affected audit fee } \\ \text { SPEC } & =\text { Indicator variable testing whether an auditor is a specialist (see Table 1) } \\ \text { CONSPEC } & =\text { Indicator variable testing the effect of concentration when the auditor is a specialist } \\ \text { CONNOSPEC } & \text { (see Table } 1 \text { ) } \\ & \text { (see Table } 1 \text { ) }\end{array}$

Table 3. Correlation Matrix

\begin{tabular}{lllllllllllllll}
\hline & 1 & 2 & 3 & 4 & 5 & 6 & 7 & 8 & 9 & 10 & 11 & 12 & 13 & 14 \\
\hline 1. Ln Size & 1.00 & & & & & & & & & & & & \\
2. Subs.5 & .56 & 1.00 & & & & & & & & & & & \\
3. Seg-ments & .42 & .37 & 1.00 & & & & & & & & & & \\
4. Foreign & .24 & .40 & .13 & 1.00 & & & & & & & & & \\
5. Recinv & -.27 & -.09 & -.08 & .07 & 1.00 & & & & & & & & & \\
6. Profit & .27 & .13 & .11 & .04 & .11 & 1.00 & & & & & & & & \\
7. Losses & -.23 & -.10 & -.09 & .04 & .07 & -.40 & 1.00 & & & & & & \\
8. Opinion & -.04 & -.02 & -.06 & -.03 & -.03 & -.29 & .15 & 1.00 & & & & & \\
9. Ln Tenure & .52 & .34 & .30 & .12 & -.07 & .21 & -.23 & -.04 & 1.00 & & & & \\
10. Sic49 & .27 & .02 & .11 & -.17 & -.35 & .07 & -.25 & .02 & .19 & 1.00 & & & & \\
11. Com-ment & .03 & .05 & .05 & .04 & -.02 & -.05 & .05 & .07 & -.00 & -.01 & 1.00 & & & \\
12. Spec & .24 & .10 & .11 & -.01 & -.13 & .09 & -.08 & -.03 & .10 & .22 & .03 & 1.00 & & \\
13. Con-spec & .07 & -.03 & -.03 & -.12 & -.22 & .06 & -.12 & -.00 & .00 & .36 & -.05 & .15 & 1.00 & \\
14. Con-nospec & .01 & -.05 & .02 & -.13 & -.05 & .11 & -.07 & .00 & -.03 & .17 & .05 & .00 & .00 & 1.00
\end{tabular}

Table 4 shows our results from regressing fees on our control and experimental variables. The model is highly significant and has an adjusted $\mathrm{R}^{2}$ of 87 percent. The model's explanatory power isquite high compared to some of the prior specialist studies. (Note 11) The test variable p-values are reported as one-tailed (directional) tests, except for CONNOSPEC, which we predicted would not be significant. The results for the COMMENT variable are highly significant and positive, indicating that circumstances specific to certain client contexts are predictive beyond the primary determinants of audit fees. Also, audit fees are higher in longer auditor-client relationships (LnTenure).

With respect to our primary variables of interest, we find that SPEC is significant and positive ( $\mathrm{p}=0.0545)$, CONSPEC is significant and negative $(\mathrm{p}=0.000)$ and CONNOSPEC is not significant. Our interpretation of these results is that specialist auditors charge more for their services (consistent with the idea of capitalizing on their special skills or reputation). With the existence of competing specialists, however, specialist auditors actually charge less for their services.

Prior literature has used different measures of concentration and specialization and even different industries (e.g., some studies did not use utility companies). Because of these differences, we next seek to determine if these results hold under alternative tests. The first alternative test we examine is the level of concentration. To determine if alternative measures of concentration might affect the results, we reran the regression model in Table 4 using two alternative measures of concentration, 80 and 70 percent. At higher levels of concentration ( 80 percent) we find marginal results that specialists (variable SPEC) still capture a premium $(\mathrm{p}=.081)$. Lower levels of concentration (70 percent) strengthen the specialist results $(\mathrm{p}=.014)$. Additionally, at higher levels of concentration, we find no change in the significance level of CONSPEC. At lower levels, however, CONSPEC significance level drops to $p$ $=.069$. In all cases the signs of these variables were unchanged at the alternative levels of concentration. These 
alternative test results are summarized in Table 5. Note that in these and subsequent alternative tests CONNOSPEC is not significant at conventional levels.

Table 4. Regression of Ln Fee on control and experimental variables

\begin{tabular}{llll}
\hline Independent Variables & Coefficient & t-statistic & \\
\hline Intercept & -4.942 & -62.461 & $* * *$ \\
Ln SIZE & .466 & 35.772 & $* * *$ \\
SUBS.5 & .062 & 8.254 & $* * *$ \\
SEGMENTS & .074 & 4.037 & $* * *$ \\
FOREIGN & 1.089 & 8.540 & $* * *$ \\
RECINV & .684 & 7.464 & $* * *$ \\
PROFIT & -.179 & -1.785 & $* *$ \\
LOSSES & .038 & .932 & \\
OPINION & .195 & 2.342 & $* * *$ \\
Ln TENURE & .068 & 2.978 & $* * *$ \\
SIC49 & -.225 & -3.286 & $* * *$ \\
COMMENT & .209 & 4.530 & $*$ \\
SPEC & .032 & 1.604 & $* * *$ \\
CONSPEC & -.099 & -2.933 & \\
CONNOSPEC & -.019 & -.829 &
\end{tabular}

F-statistic: 313.18

Adjusted $\mathrm{R}^{2}: .87$

$* * * \mathrm{p}<.01$

$* * \mathrm{p}<.05$

$* \mathrm{p}<.10$

\begin{tabular}{ll}
\hline Ln SIZE & $=$ Natural log of total assets in millions \\
SUBS.5 & $=$ Square root of the number of subsidiaries \\
SEGMENTS & $=$ Number of business segments \\
FOREIGN & $=$ Percentage of assets that are foreign \\
RECINV & $=$ Accounts receivable plus inventory divided by assets \\
PROFIT & $=$ Net income divided by total assets \\
LOSSES & $=$ One if a loss in the past three years \\
OPINION & $=$ One if audit opinion is modified for going concern \\
Ln TENURE & $=$ Natural log of the number of years with the same auditor \\
SIC49 & $=$ One if company is a utility company. \\
COMMENT & $=$ One if significant event affected audit fee \\
SPEC & $=$ Indicator variable testing whether an auditor is a specialist (see \\
CONSPEC & Table 1 ) \\
& $=$ Indicator variable testing the effect of concentration when the \\
CONNOSPEC & $=$ Indicator variable testing the effect of concentration when the \\
& auditor is not a specialist (see Table 1)
\end{tabular}


The sample and model in Table 4 includes utility companies (SIC49) and also includes an indicator variable for utility companies. To ensure that utilities werenot causing our results and to provide additional comparability, we reran the model without utilities. Results reported in Table 5 in the row titled "No utilities in the sample" show that the variable, CONSPEC is still significant $(p=.012)$. The results for SPEC are stronger $(p=.023)$. The signs on the variables did not change. This suggests that utility companies do not drive our results.

One further alternative test was to determine whether the results were sensitive to our measure of specialists. To test the sensitivity of our results to an alternative measure of specialist, we reran our regression model using a 25 percent level of specialist. That is, we coded specialist as any auditor having at least 25 percent of the market and then applied the same coding scheme described in Table 1. Results from this alternative test are reported on the last row of Table 5. SPEC still has a positive sign but the significance level drops to $p=.084$ reflecting weaker results. Our previous result on the variable CONSPEC, reported in Table 4,is not substantially changed by the new 25 percent specialist measure. The coefficient on CONSPEC is still negative and significant $(-.126, p<.01)$.

Table 5. Results From Alternative Measures of Test Variables

\begin{tabular}{llll}
\hline Alternative Measure: & \multicolumn{2}{l}{ Variable and Coefficient: } \\
\hline & SPEC & CONSPEC & CONNOSPEC \\
$80 \%$ concentration & $.028^{*}$ & $-.107^{* * *}$ & .040 \\
$70 \%$ concentration & $.053^{* *}$ & $-.061^{*}$ & .031 \\
No utilities in the sample & $.043^{* *}$ & $-.080^{* *}$ & -.027 \\
$25 \%$ specialist & $.037^{*}$ & $-.126^{* * *}$ & -.032 \\
$* * * \mathrm{p}<.01$ & & & \\
$* * \mathrm{p}<.05$ & & & \\
$* \mathrm{p}<.10$ & & & \\
\hline
\end{tabular}

\section{Conclusions}

The GAO continues to focus attention on the market for public company audits. Over the past 30 years, the number of large accounting firms has decreased from what was known as the "Big 8" to the "Big 4". With the resulting increased concentration, the GAO and Congress are concerned that the competiveness of the remaining 4 firms might be impaired. Because of the GAO's interest in possiblyreturning to a market that would consist of more than 4 large accounting firms, we conduct a retrospective look at pricing behavior in the less concentrated Big 6 audit market. We find that the effect of specialization and concentration on audit fees isinterconnected. Our results are generally robust to alternative measures of concentration and specialization and to the inclusion of utility companies. These very intuitive results reveal that Big 6 specialists charge a premium for their services unless they are in direct competition with other specialists.

The 2008 GAO report notes that theirresultsare not strong enough for one to conclude that the audit services market is competitive. Furthermore, their data does not reach beyond the year 2006. Future research could compare and contrast the results reported herein with data from the Big 5 and Big 4 markets and also to data from the post Sarbanes Oxley time period. With the benchmark data we provide from the Big 6 era, future work can help regulators understand further the interaction between concentration and specialization and their interactive effect on the cost of audit services.

\section{References}

Abbott, L. \& S. Parker. (2000). Auditor selection and audit committee characteristics. Auditing: A Journal of Practice and Theory, 19 (2): 47-67.

Beattie, V. \& S. Fearnley. (1995). The importance of audit firm characteristics and the drivers of auditor change in UK listed companies. Accounting and Business Research, 25 (100): 227-239. http://dx.doi.org/10.1080/00014788.1995.9729912

Bigus, J. \& R. Zimmermann. (2008). Non-audit fees, market leaders and concentration in the German audit market: A descriptive analysis. International Journal of Auditing, 12 (3): 159-179. http://dx.doi.org/10.1111/j.1099-1123.2008.00378.x 
Buckless, F. A., \& S. P. Ravenscroft. (1990). Contrast coding: a refinement of ANOVA in behavioral analysis. The Accounting Review, 65: 933-945.

Casterella, J. R., J. R. Francis, B. L. Lewis, \& P. L. Walker. (2004). Auditor industry specialization, client bargaining power, and audit pricing. Auditing: A Journal of Practice \& Theory,23 (1): 123-140.

Craswell, A. T., J. R. Francis, \& S. L. Taylor. (1995). Auditor brand name reputations and industry specializations. Journal of Accounting and Economics, 20: 297-322. http://dx.doi.org/10.1016/0165-4101(95)00403-3

DeAngelo, L. E. (1981). Auditor size and audit quality. Journal of accounting and economics,3 (3): 183-199. http://dx.doi.org/10.1016/0165-4101(81)90002-1

DeFond, M. L., J. Francis, \& T. J. Wong. (2000). Auditor industry specialization and market segmentation: Evidence from Hong Kong. Auditing: A Journal of Practice \& Theory, 19: 49-66.

Francis, J. (1984). The effect of audit firm size on audit prices: a study of the Australian market. Journal of Accounting and Economics, 6: 133-151. http://dx.doi.org/10.1016/0165-4101(84)90010-7

Government Accountability Office. (GAO). (2003). Public Accounting Firms: Mandated Study on Consolidation and Competition.

Government Accountability Office. (GAO). (2008). Report to Congressional Addressees: Audits of Public Companies. Continued Concentration in Audit Market for Large Public Companies Does Not Call for Immediate Action.

Hay, D. C., W. R. Knechel, W. R. \& N. Wong. (2006). Audit fees: A meta-analysis of the effect of supply and demand attributes. Contemporary Accounting Research, 23: 141-191. http://dx.doi.org/10.1506/4XR4-KT5V-E8CN-91GX

Judd, C. M., \& G. H. McClelland. (1989). Data Analysis: A Model-Comparison Approach. Harcourt Brace Jovanovich.

Kallapur, S., S. Srinivasan \& Z. Yoonseok. (2010). Audit market concentration and audit quality (February 2, 2010). http://dx.doi.org/10.2139/ssrn.1546356

Palmrose, Z. (1986). Audit fees and auditor size: further evidence. Journal of Accounting Research,24: 97-110. http://dx.doi.org/10.2307/2490806

Pearson, T., \& G. Trompeter. (1994). Competition in the market for audit services: the effect of supplier concentration on audit fees. Contemporary Accounting Research, 11: 115-135. http://dx.doi.org/10.1111/j.1911-3846.1994.tb00439.x

Simunic, D. (1980). The pricing of audit services: theory and evidence. Journal of Accounting Research, 18: 161-190. http://dx.doi.org/10.2307/2490397

Wolk, M. C., S. E. Michelson \& C. W. Wooton. (2001). Auditor concentration and market shares in the US: 1988-1999 A descriptive note. The British Accounting Review, 33 (2): 157-174. http://dx.doi.org/10.1006/bare.2001.0159 


\section{Notes}

Note 1. Beattie and Fearnley's (1995) results suggest that specialist industry knowledge is an important factor to client companies.

Note 2. Examples provided are Standard Oil and the American Tobacco Company in 1911 and more recently AT\&T. Note 3. A list of variable definitions is provided in Simunic (1980).

Note 4. Note that our coding in Table 2 meets the two conditions for defining contrast codes. The first condition is that for a categorical variable coded with values of $\mathrm{k}$, where the $\mathrm{k}$ refers to the level of the coded variable, the sum of the 's across the levels of the categorical variable must equal zero. In Table 2, this means that summing across the variable SPEC, we get the values $+1,+1,-1$ and -1 , which sum to zero. The second condition requires that across levels of the categorical variable all pairs of contrast codes must be orthogonal. This means that the many sums of the products of 's must equal zero. An example of this condition from Table 2 for SPEC and CONSPEC can be demonstrated as follows: $1(1)+1(-1)+-1(0)+-1(0)=0$. This second condition implies that any contrast code can't be chosen in isolation but rather must be considered in the context of the other codes.

Note 5. A discussion of our survey questionnaire is presented in Section 4.

Note 6. As explained in Francis (1984), controlling for size with an independent variable eliminates the heteroscedasticity encountered when fees are deflated by size.

Note 7. The survey instrument is available from the authors upon request.

Note 8. Since our sample only includes Big 6 auditors, this allows us to focus on the effect of specialization and concentration while simultaneously controlling for the effect of a Big 6 premium. This same approach was used by Craswell et al. (1995).

Note 9. We did not use the internal audit budget variable in this paper because we later realized we should have asked for actual internal audit expenditures expended on assisting with the external audit and because the variable, as captured, is not significant in the model.

Note 10. The one possible exception to this statement is the correlation between SIC49 and the experimental variables. In a later section, we test and discuss the sensitivity of our results to SIC49.

Note 11. We found no violations of the regression assumptions of normally distributed residuals and constant variance. We also noted no variance inflation factors greater than 2.2 (most were below 2). 